
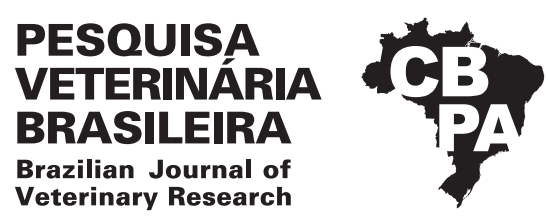

Pesq. Vet. Bras. 39(7):530-537, July 2019 DOI: $10.1590 / 1678-5150-P V B-5790$

ISSN 0100-736X (Print) ISSN 1678-5150 (Online)

\title{
Use of infrared thermography in Quarter Horse submitted to team roping ${ }^{1}$
}

\author{
Bianca Gerardi ${ }^{2 *}$ (D) Daniela S. Denadai², Mariana S. Pereira², Arthur A. Chaves², \\ João P.B. Barbosa ${ }^{2}$, Juliana R. Peiró ${ }^{2}$, Francisco L.F. Feitosa ${ }^{2}$ and Luiz C.N. Mendes ${ }^{2}$
}

\begin{abstract}
Gerardi B., Denadai D.S., Pereira M.S., Chaves A.A., Barbosa J.P.B., Peiró J.R., Feitosa F.L.F. \& Mendes L.C.N. 2019. Use of infrared thermography in Quarter Horse submitted to team roping. Pesquisa Veterinária Brasileira 39(7):530-537. Departamento de Clínica, Cirurgia e Reprodução Animal, Universidade Estadual Paulista "Julio de Mesquita Filho", Campus de Araçatuba, Rua Clóvis Pestana 793, Araçatuba, SP 16050-680, Brazil. E-mail: bi gerardi@hotmail.com

This study aimed to verify whether the body and local temperatures change after high-intensity, short-duration exercise (team roping) and whether different pieces of training influence these changes. To this end, twelve animals, males and females, aged 3-6 years, with an average weight of $450 \mathrm{~kg}$, were used. The horses were divided into two groups: regular training (RTG) and sporadic training (STG). The surface temperatures were assessed using a specific thermal camera. Temperatures of the ocular, thoracolumbar, distal tendon (thoracic and pelvic limbs) and croup regions were measured $30 \mathrm{~min}$ before, immediately after, and one, two, six and 24 hours after competition simulation. In the RTG, there was an increase in surface eye temperature two hours after exercise, returning to baseline level 24 hours later. In the STG, increase in eye temperature occurred immediately after exercise and returned to baseline level two hours later. Temperature of the pelvic limb tendons and croup (right side) rose immediately after exercise and did not return to baseline level 24 hours later. Team roping exercise increased the surface temperature of the distolateral thoracic and pelvic limb, croup and thoracolumbar regions in both groups and the eye temperature in the STG. Training frequency influenced the surface temperature profile in the distolateral pelvic limb, croup and thoracolumbar regions.
\end{abstract}

INDEX TERMS: Infrared thermography, Quarter Horse, team roping, exercise, horses, inflammation, thermoregulation.

RESUMO.- [Uso da termografia infravermelha em equinos da raça Quarto de Milha submetidos à prova de laço em dupla.] Os objetivos do presente estudo foram verificar se as temperaturas corpóreas e locais se alteram após exercício de alta intensidade e curta duração (prova de laço em dupla) e se treinamentos distintos podem influenciar nestas alterações. Foram utilizados 12 animais, machos e fêmeas, com idade entre

\footnotetext{
${ }^{1}$ Received on November 29, 2018.

Accepted for publication on January 16, 2019.

Doctoral Dissertation research with FAPESP support.

${ }^{2}$ Departamento de Clínica, Cirurgia e Reprodução Animal, Universidade Estadual Paulista "Julio de Mesquita Filho" (Unesp), Campus de Araçatuba, Rua Clóvis Pestana 793, Araçatuba, SP 16050-680, Brazil. E-mails: daniela_denadai@hotmail.com,marijeronymo@hotmail.com, arthur@unisalesiano.com.br, joaopedro.vet@gmail.com, jpeiro@fmva.unesp.br, leydsonf@fmva.unesp.br, lmendes@fmva.unesp.br; *Corresponding author: bi gerardi@hotmail.com
}

3 e 6 anos e peso médio de $450 \mathrm{~kg}$. Os animais foram divididos em dois grupos: treino regular (GTR) e treino esporádico (GTE). As aferições da temperatura por meio de termografia infravermelha foram feitas por uma câmera termal específica. As medições das temperaturas das regiões ocular, toracolombar, tendíneas distais (membros torácicos e pélvicos) e garupa foram realizadas 30 minutos antes, imediatamente depois, uma, duas, seis e 24 horas após a simulação de competição. No GTR houve aumento de temperatura ocular duas horas após o exercício, retornando ao basal apenas 24 horas depois. No GTE o aumento ocorreu imediatamente após o exercício e retornando ao basal duas horas depois. As temperaturas da região dos tendões dos membros pélvicos e garupa (lado direito) elevaram-se imediatamente após o exercício e não retornaram ao basal após 24 horas. 0 exercício de laço em dupla aumentou as temperaturas superficiais nas regiões distolateral de membros torácicos e pélvicos, garupa e região 
toracolombar de ambos os grupos e da temperatura ocular do GTE. A frequência de treinamento influenciou o perfil de temperatura superficial na região distal de membros pélvicos, garupa e toracolombar.

TERMOS DE INDEXAÇÃO: Termografia infravermelha, Quarto de Milha, prova de laço, equinos, exercício, inflamação, termorregulação.

\section{INTRODUCTION}

Brazil has a population of approximately five million equines, one million of which are intended for sports and leisure (Lima \& Cintra 2016). Considering only Quarter Horse and its cross-breeds, there was a population of 460 thousand registered animals in 2017 (Associação Brasileira do Quarto de Milha 2018). The economic market associated with sport and leisure horses is of approximately USD 5.84 billion/year (Lima \& Cintra 2016). Care of these equine athletes is of utmost importance, thus the monitoring of athletic performance and clinical status of these animals is essential for the development of healthy and high-performance horses.

Team roping is one of the most common modalities practiced with Quarter Horses, an event in which two mounted riders rope a steer: the first roper (header) is responsible for roping the head or horns, while the second roper (heeler) should rope the hind limbs. The competition takes eight to ten seconds on average, from the time the riders come out of the box until the steer is caught and held by stretched ropes tied to the saddles of the horses. The team that completes the task in the shortest time wins (Caiado et al. 2011). After roping the steer, the horse ridden by the header makes a 90-degree turn to the left, positioning its right thoracic limb cranially and laterally to decelerate and drag the steer, placing weight and strength on the right thoracic limb. The horse mounted by the heeler makes a quick left turn to position itself to the left side of the steer so that the hind limbs can be roped; after that, the horse stops abruptly, which can injure its pelvic limbs (Dabareiner 2011).

Infrared thermography is a noninvasive technique with potential for real-time diagnosis of local inflammation, which can lead to clinical disease (Simon et al. 2006). Through this method, it is possible to identify changes on skin surface temperature, which is directly associated with underlying circulation, tissue metabolism, and local blood flow (Eddy et al. 2001, Tunley \& Henson 2004). Local temperature increase may be a result of an inflammatory process caused by increased local circulation (Simon et al. 2006) or physical exercise in response to the production of heat by muscle contractions (Hodgson 2014). Temperature measurements taken from muscle biopsy have shown positive correlations between muscle temperature and exercise duration in horses. Results showed a gradual increase in temperature with continued exercise, reaching an average temperature of $38.8^{\circ} \mathrm{C}$ (Lovell et al. 1987).

Thermographic image assessment of a muscle can be performed by comparing the same anatomical regions on opposite sides. Under normal situation, the images should be almost identical. Significant changes in these regions may indicate muscle injury (Yanmaz et al. 2007). In addition, this diagnostic method can detect local temperature changes even before detection by direct palpation. Significant tissue changes can be diagnosed up to two weeks prior to the occurrence of other clinical signs (Turner et al. 2001). Increased serum muscle enzyme concentration indicates muscle injury only, but not exactly which muscle or muscle group is involved. In contrast, thermography can identify the individual affected structures (Turner 2011).

Previous studies (Schaefer et al. 2007, Dunbar et al. 2009, Johnson et al. 2011) have shown that changes in temperature in the ocular region are associated with altered body temperature. Infrared thermography has been used as a quick, painless, easy-to-perform method for controlling fever in cattle with respiratory diseases (Schaefer et al. 2007). Dunbar et al. (2009) demonstrated no difference between the eye and rectal temperatures measured by thermography in deer. In horses, infrared thermography of the ocular region has proved to be a good indicator of body temperature, and when the use of maximum eye temperature revealed $74.6 \%$ sensitivity for detecting (Johnson et al. 2011).

It has been demonstrated that long-term, high-intensity physical exercises, such as cross country, enduro, and treadmill (Simon et al. 2006, Costa et al. 2009), cause changes in both body and local temperatures. Nevertheless, there are few studies reporting changes in temperature in animals submitted to team roping (Gomide et al. 2014). Therefore, the present study aimed to verify whether surface temperatures of the medial eye, distolateral thoracic and pelvic limb, croup, and thoracolumbar regions change after team roping, and whether different pieces of training can influence these changes.

\section{MATERIALS AND METHODS}

Characterization of the animals. The present study was duly assessed and approved by the Ethics Committee on Animal Use (CEUA) of Unesp, Campus Araçatuba under protocol no. 2012-01985.

Twelve clinically healthy Quarter Horses, males and females, with an average weight of $450 \mathrm{~kg}$, participants in the team roping modality were used in this research. The animals were submitted to similar general training programs - same intensity, velocity and duration, always conducted by the same trainer, differing only with respect to frequency. All of them also had a rest period of at least 24 hours prior to experiment commencement. The sample was divided into two groups according to training frequency: regular training group (RTG, trained five times a week), composed of six horses, three males and three females, with mean age of 3.8 years $( \pm 0.83)$; sporadic training group (STG, trained twice a week), comprising six horses, three males and three females, with mean age of 6 years $( \pm 1.3)$. Of the six animals in each group, three were mounted by headers and three were ridden by heelers. The experiment was conducted at an equine training center in the municipality of Araçatuba, Sao Paulo state, Brazil, where the animals were kept in individual stalls and fed Tifton hay and pelleted commercial feed twice daily, in addition to mineral salt once a day and water ad libitum.

Competition simulations were conducted on two different days, always in the morning, from 8 to 11 a.m., with mean environment temperature of $29.2^{\circ} \mathrm{C}$ and relative humidity of $60.2 \%$. The simulations were performed in a covered sand track in the training center. The Quarter Horses were randomly selected; half of the animals in the RTG and STG participated in the first simulation and the remaining horses were involved in the second simulation. The animals were submitted to team roping for five consecutive times, always conducted by the same pair of riders. The simulations lasted $15 \mathrm{~min}$ for each animal, on average. Prior to exercise, all animals underwent a warm-up period of approximately $20 \mathrm{~min}$ : $5 \mathrm{~min}$ at walk, $10 \mathrm{~min}$ at trot, and $5 \mathrm{~min}$ at gallop, in a $7 \mathrm{~m}$ circular path. All horses were 
warmed by the same trainer and were subsequently submitted to exercise without resting.

Thermography. The study was conducted during the summer, more specifically in January. Surface temperatures of the ocular, thoracic and pelvic limb tendon (superficial and deep digital flexors), thoracolumbar and croup regions were measured by infrared thermographic imaging on both sides. These temperatures were measured using a thermal camera $\left(\right.$ FLIR $^{\circledR} \mathrm{i} 60$, USA) with 0.95 adjusted emissivity, $\pm 2 \%$ accuracy, and $0.1^{\circ} \mathrm{C}$ sensitivity, in real time, at a $1 \mathrm{~m}$ distance. Temperature measuring times were as follows: prior to exercise (M0); immediately after exercise (M1); one (M2), two (M3), six (M4), and 24 (M5) hours after exercise. The animals were kept in the shade, at room temperature, both at the time of team roping simulation and during the intervals between temperature measurements. The recorded images were analyzed using specific software (FLIR ${ }^{\circledR}$ Tools, 5.5, USA), and the surface temperatures were also corrected in relation to ambient temperature and relative humidity. The maximum ocular temperatures were measured in the medial corner of the eyes. As for the region of the distal tendons of the thoracic and pelvic limbs, analyses were performed in a rectangular area that extended from the carpometacarpal to the metacarpophalangeal joints in the thoracic limb and from the tarsometatarsal to the metatarsophalangeal joints in the pelvic limb. Measurement in the croup region (upper and lower gluteal muscles) was performed on the right and left sides in a circular area, and analysis of the spine was conducted by linearity. Environment temperature and relative humidity (Table 1) were monitored before each re-calibration of the surface temperatures using specific equipment (KLIMMALOGG PRO Thermo-Hygro-Station TFA ${ }^{\circledR}$, Germany).

Statistical analysis. Data were tested for normality and homogeneity of variances - prerequisites for analysis of variance. The data obtained for maximum eye temperature and mean temperatures of the spine, croup, and thoracic and pelvic limbs were subjected to analysis of variance (ANOVA) with repeated measurements for comparison between groups and measuring times, followed by multiple comparisons of the means by the Tukey's test at $5 \%$ significance level. Differences were considered statistically significant when $p<0.05$ and the data were processed using the SAS software (SAS Institute Inc. 2014).

Table 1. Absolute and mean values and standard deviation of environment temperature $\left({ }^{\circ} \mathrm{C}\right)$ and relative humidity $(\%)$ at the different surface temperature measuring times using infrared thermography in Quarter Horses submitted to team roping: regular training (RTG) and sporadic training (STG) groups

\begin{tabular}{|c|c|c|c|c|c|c|c|c|}
\hline & \multirow{2}{*}{ Animal } & \multirow{2}{*}{ Environment } & \multicolumn{6}{|c|}{ Measuring times } \\
\hline & & & $\mathrm{M}^{\mathrm{a}}$ & M1 ${ }^{\mathrm{b}}$ & $\mathrm{M} 2^{\mathrm{c}}$ & M3 ${ }^{d}$ & $\mathrm{M} 4^{\mathrm{e}}$ & $\mathrm{M}^{\mathrm{f}}$ \\
\hline \multirow{12}{*}{ RTG } & 1 & $\mathrm{~T}$ & 28.6 & 28.8 & 31.3 & 33.2 & 39 & 31 \\
\hline & & RH & 60 & 62 & 53 & 48 & 30 & 56 \\
\hline & 2 & $\mathrm{~T}$ & 26.6 & 28.6 & 31.3 & 33 & 39 & 31.5 \\
\hline & & RH & 70 & 61 & 53 & 49 & 49 & 54 \\
\hline & 3 & $\mathrm{~T}$ & 26.8 & 30.4 & 32.3 & 34.4 & 38.7 & 31.8 \\
\hline & & RH & 68 & 58 & 52 & 44 & 33 & 52 \\
\hline & 4 & $\mathrm{~T}$ & 22.7 & 26.4 & 28.1 & 30.5 & 35.4 & 27 \\
\hline & & RH & 80 & 71 & 63 & 56 & 45 & 67 \\
\hline & 5 & $\mathrm{~T}$ & 22.6 & 26.9 & 28.6 & 31.3 & 33.9 & 27.6 \\
\hline & & $\mathrm{RH}$ & 81 & 68 & 62 & 52 & 47 & 64 \\
\hline & 6 & $\mathrm{~T}$ & 22.5 & 24.5 & 27.1 & 28.8 & 31.8 & 25.2 \\
\hline & & RH & 82 & 76 & 68 & 61 & 55 & 70 \\
\hline Mean temperature & & $\mathrm{T}$ & $24.9 \pm 2.7$ & $27.6 \pm 2.1$ & $29.8 \pm 2.1$ & $31.8 \pm 2.1$ & $36.3 \pm 3.1$ & $29.0 \pm 2.8$ \\
\hline Mean relative humidity & & RH & $73.5 \pm 8.9$ & $66.0 \pm 6.8$ & $58.5 \pm 6.7$ & $51.7 \pm 6.1$ & $43.2 \pm 9.7$ & $60.5 \pm 7.5$ \\
\hline \multirow{12}{*}{ STG } & 7 & $\mathrm{~T}$ & 26.7 & 29.6 & 31.7 & 33.6 & 39.2 & 31.6 \\
\hline & & RH & 68 & 62 & 54 & 45 & 29 & 54 \\
\hline & 8 & $\mathrm{~T}$ & 26.9 & 30.9 & 31.7 & 33.6 & 39.6 & 31.6 \\
\hline & & RH & 68 & 56 & 53 & 46 & 31 & 54 \\
\hline & 9 & $\mathrm{~T}$ & 27.2 & 30.4 & 32.4 & 34.4 & 38.8 & 31.7 \\
\hline & & RH & 66 & 58 & 52 & 44 & 31 & 52 \\
\hline & 10 & $\mathrm{~T}$ & 22.7 & 26.8 & 28.8 & 31.4 & 33.5 & 28.3 \\
\hline & & RH & 82 & 70 & 60 & 52 & 47 & 63 \\
\hline & 11 & $\mathrm{~T}$ & 22.8 & 24.5 & 27.4 & 28.2 & 33.4 & 25.5 \\
\hline & & RH & 82 & 76 & 66 & 59 & 51 & 70 \\
\hline & 12 & $\mathrm{~T}$ & 23.7 & 25.9 & 28.2 & 28.7 & 33.5 & 23.8 \\
\hline & & RH & 76 & 69 & 62 & 64 & 51 & 77 \\
\hline Mean temperature média & & $\mathrm{T}$ & $25.0 \pm 2.2$ & $28.0 \pm 2.6$ & $30.0 \pm 2.1$ & $31.7 \pm 2.7$ & $36.3 \pm 3.2$ & $28.8 \pm 3.5$ \\
\hline Mean relative humidity & & $\mathrm{RH}$ & $76.7 \pm 7.3$ & $65.1 \pm 7.8$ & $57.8 \pm 5.7$ & $51.7 \pm 8.3$ & $40.0 \pm 10.7$ & $61.7 \pm 10.2$ \\
\hline
\end{tabular}

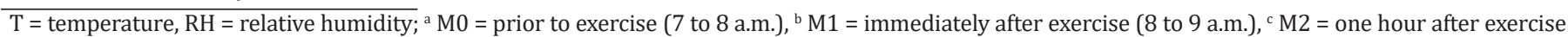
(9 to 10 a.m.), ${ }^{\mathrm{d}} \mathrm{M} 3$ = two hours after exercise (10 to 11 a.m.), ${ }^{\mathrm{e}} \mathrm{M} 4=$ six hours after exercise ( 2 to 3 p.m.), ${ }^{\mathrm{f}} \mathrm{M} 5=24$ hours after exercise ( 7 to 8 a.m.). 


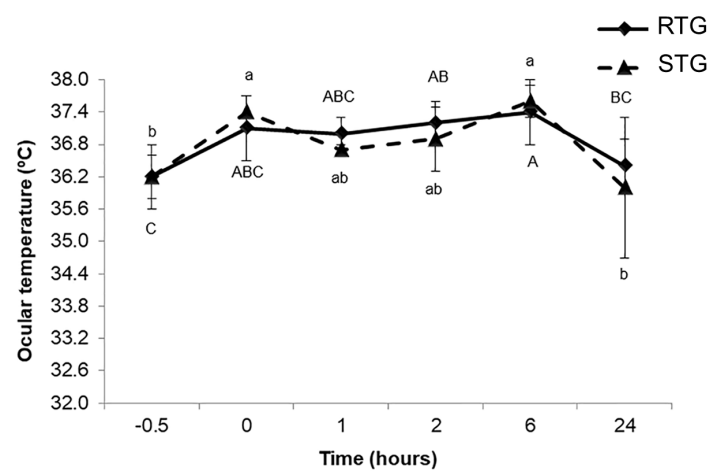

Fig.1. Maximum values and standard deviation of surface eye temperature $\left({ }^{\circ} \mathrm{C}\right)$ in Quarter Horses submitted to team roping: regular training (RTG) and sporadic training (STG) groups. Means followed by the same uppercase letters do not differ over time in the RTG by the Tukey's test ( $p>0.05$ ). Means followed by the same lowercase letters do not differ over time in the STG by the Tukey's test $(p>0.05)$.

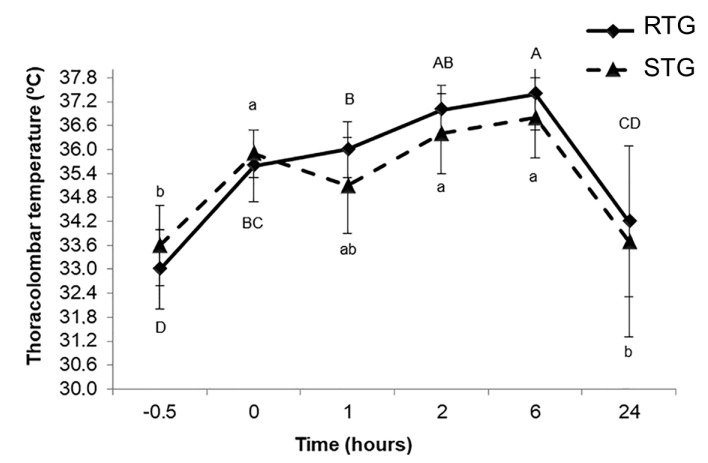

Fig.2. Mean values and standard deviation of surface thoracolumbar temperature $\left({ }^{\circ} \mathrm{C}\right)$ in Quarter Horses submitted to team roping: regular training (RTG) and sporadic training (STG) groups. Means followed by the same uppercase letters do not differ over time in the RTG by the Tukey's test ( $p>0.05$ ). Means followed by the same lowercase letters do not differ over time in the STG by the Tukey's test $(p>0.05)$.

\section{RESULTS}

With respect to the ocular region, a significant increase in temperature was observed in the RTG two hours after exercise compared with 30 minutes before exercise, remaining high for further four hours. In the STG, the increase occurred immediately after exercise, returned to baseline one hour later, and remained at this level for another hour, rising again after six hours compared with that at baseline level. After 24 hours, the temperature returned to baseline in both groups (Fig.1).

Regarding the thoracolumbar region, there was a significant increase in temperature in both groups immediately after exercise. In the RTG, the temperature returned to baseline level only 24 hours after exercise, whereas in the STG, the temperature returned baseline level one hour after exercise. However, the temperature rose and remained above the baseline level between two and six hours after exercise, equaling it after 24 hours (Fig.2).

As for the croup region, the temperature profile was the same in the RTG (left side) and STG (right side). A significant increase was verified immediately after exercise, returning to the baseline level only after 24 hours. On the left side in the STG, a significant increase in temperature was observed immediately after exercise, but it returned to baseline level one hour later, rising again at two and six hours after exercise, and returning to baseline only 24 hours later. On the right side in the RTG, the temperature rose immediately after exercise and remained high for up to 24 hours (Fig.3A,B).

Concerning the tendon region of the thoracic limbs, the temperature rose significantly shortly after exercise and returned to baseline level 24 hours later on both sides, in both groups (Fig.4A,B). The same temperature changes were found in the region of the pelvic limbs in the STG, whereas in the RTG, there was no return to the baseline level in the right pelvic limb (RPL) and left pelvic limb (LPL) tendon regions 24 hours after exercise. The temperature rose significantly immediately after exercise and remained high (Fig.4C,D).

No statistically significant difference was observed between the study groups regarding the surface temperatures of the measured regions.
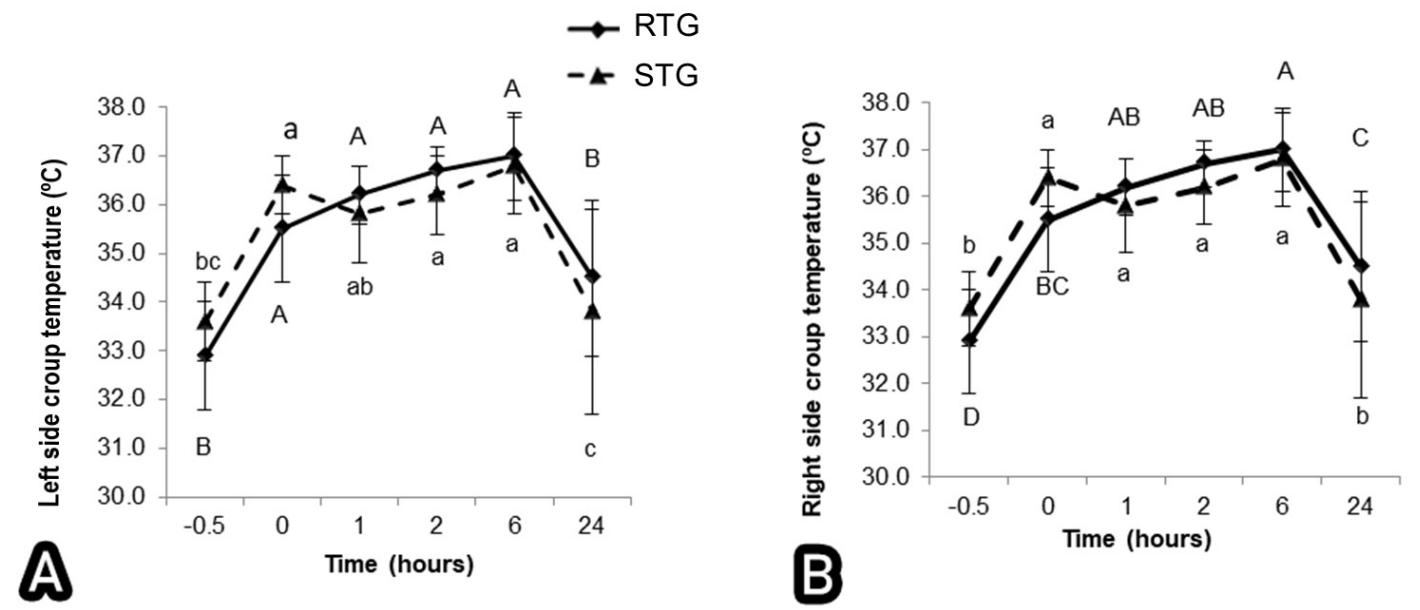

Fig.3. Mean values and standard deviation of surface croup temperatures $\left({ }^{\circ} \mathrm{C}\right),(\mathbf{A})$ left and $(\mathbf{B})$ right sides, in Quarter Horses submitted to team roping: regular training (RTG) and sporadic training (STG) groups. Means followed by the same uppercase letters do not differ over time in the RTG by the Tukey's test $(p>0.05)$. Means followed by the same lowercase letters do not differ over time in the STG by the Tukey's test $(p>0.05)$. 

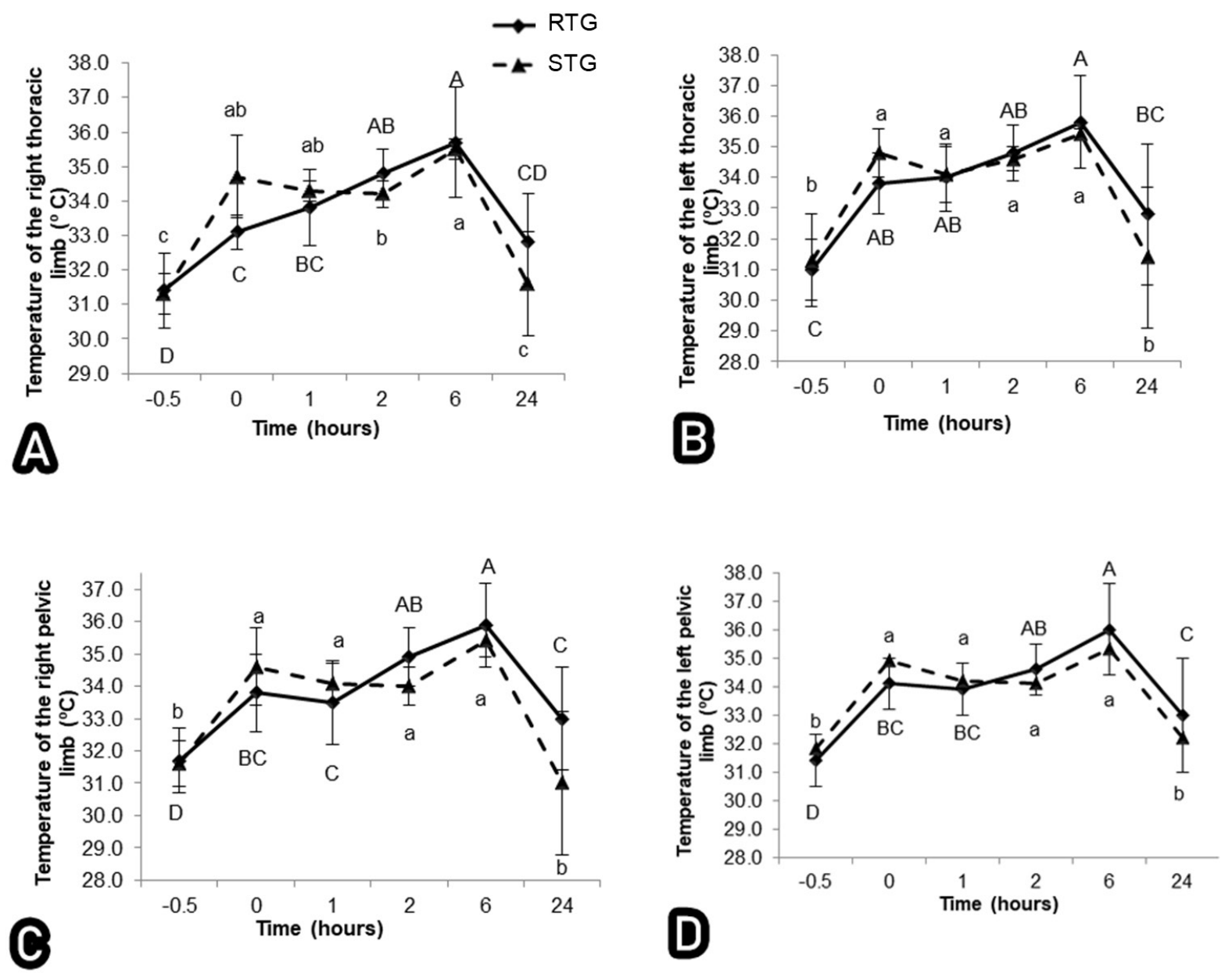

Fig.4. Mean values and standard deviation of surface temperatures $\left({ }^{\circ} \mathrm{C}\right)$ in the regions of the (A) right thoracic limb (RTL), $(\mathrm{B})$ left thoracic limb (LTL), (C) right pelvic limb (RPL) and (D) left pelvic limb (LPL), in Quarter Horses submitted to team roping: regular training (RTG) and sporadic training (STG) groups. Means followed by the same uppercase letters do not differ over time in the RTG by the Tukey's test $(p>0.05)$. Means followed by the same lowercase letters do not differ over time in the STG by the Tukey's test $(p>0.05)$.

\section{DISCUSSION}

Findings of the present study showed an increase in temperature in the ocular region after team roping simulation in the STG, suggesting that even short duration exercise can cause alteration in eye temperature. Because no significant changes in eye temperature were observed between the groups, we conclude that the training frequency did not influence the rate of central heat production. Although eye temperature is considered an alternative tool for non-invasive central temperature measurement (Schaefer et al. 2007, Dunbar et al. 2009, Johnson et al. 2011), in the present study, some measurements showed values below normal for the species; these results were probably influenced by the measurement distance. It has previously been demonstrated that measurement distances $<1 \mathrm{~m}$ present higher accuracy between rectal and maximum eye temperatures in horses (Johnson et al. 2011).

Absence of significant increase in eye temperature immediately after exercise in the RTG may be associated with a higher adaptive capacity of these animals. Animals in the RTG are believed to have a higher cardiac output than those in the STG, enabling greater redistribution of blood to organs and tissues participating in thermolysis, including the skin, respiratory muscles, and nasal mucosa (McConaghy et al. 1996), consequently promoting faster heat dissipation and not causing significant temperature change.

Decrease in temperature observed in the animals of the STG one hour after exercise was associated with the thermoregulatory activation mechanism in an attempt of these horses to avoid post-exercise hyperthermia. It is common knowledge that the capacity to modify the irrigation of different organs, adjusting it to different needs, is a characteristic of the cardiovascular system that efficiently assists with thermoregulation (McConaghy et al. 1996). The results obtained in this study show that the thermoregulatory mechanism was also efficient in the STG, since the temperatures in the thoracolumbar, croup and ocular regions returned to the baseline level one hour after the exercise. Although temporarily away from competitions and resuming training, the animals in the STG are conditioned to exercise, which explains the efficiency of their thermoregulation mechanism. According to Hodgson (2014), the faster the animal returns to baseline frequencies and temperatures, the better its athletic conditioning.

Increase in surface temperature in the ocular, thoracolumbar and croup regions two and six hours after exercise coincides 
with the elevation of ambient temperature, which hinders heat exchange. Considering that one of the forms of heat exchange occurs by convection, through the movement of air on the surface of a body as during exercise, and that this heat exchange is efficient only when the temperature of the air that surrounds the animal is lower than its skin temperature (McConaghy 1994), when keeping the animals of the present study standing still, even in a shaded place, heat exchange became dependent on the movement of circulating air, which did not occur during the experiment. Therefore, absence of air circulation along with increased environment temperature at these times has hindered heat loss by convection. In addition, the increase in ambient temperature, which at certain times was higher than the body temperature of healthy horses $\left(37.5-38.5^{\circ} \mathrm{C}\right)$, promoted heat gain in the animals of both groups. According to Robertshaw (2006), animals gain or lose heat by conduction or convection through direct contact with hot or cold substances, including air. Another form of heat gain is through radiation; even if not directly exposed to sunlight, the body surface of an animal absorbs heat from the environment around it through long-wave radiation.

According to Tanda (2016), increased ambient temperature results in increased central temperature, with consequent activation of the thermoregulatory mechanism. Although vasodilatation facilitates heat exchange of the animal with the environment through sensitive processes, the effectiveness thereof depends on the thermal gradient between the animal's body and the ambient temperature (Mccutcheon \& Geor 2008).

Regarding the temperatures in the assessed regions, the results obtained evidenced heat production in all of these regions after exercise and, consequently, a rise in the local temperatures. Temporary increase in temperature occurs primarily due to the increase in muscle metabolism, as well as to increased blood flow in the region, with the aim of increasing oxygen supply and heat dissipation. In humans, for instance, blood flow may present a 20 -fold increase at exercise peak compared with the resting state (Lash 1996). However, when exercise ceases, the flow tends to normalize with return of the temperature to the baseline level (Hodgson \& Rose 1994). In this study, the temperatures of all analyzed areas returned to baseline level, except for the regions of the right and left pelvic limb tendons and the right side of the croup of horses in the RTG.

In the RTG, the temperature of the tendon region in the left and right pelvic limbs did not return to baseline level after 24 hours. These results are in disagreement with those reported in previous studies, which showed that temperature in the tendon region of the pelvic limbs of horses submitted to exercise on treadmill - consisting of five minutes at walk, slow trot, trot, and slow gallop, then back to 3-min trot, slow trot, and walk - returned to baseline level 45 minutes after exercise (Simon et al. 2006). In the present study, it was observed that, before 24 hours after exercise, the surface temperatures of several regions returned to the baseline level; therefore, the thermoregulation mechanism of these animals was functional. Thus, it is possible to conclude that the temperature increase in these regions is not associated with failure in the heat loss process, but probably with the greater burden on these areas demanded by team roping.

The difference between the results of the present study and those presented by Simon et al. (2006), probably lies on the greater tension on the tendon and ligament structures of the pelvic limbs in horses undergoing team roping. Animals in this sport modality are submitted to a greater burden on the pelvic tendons at the start and roping completion times. At the latter time, the horse mounted by the heeler stops abruptly after the hind limbs of the steer are roped, and the horse ridden by the header turns $180^{\circ}$ to stop in front of the steer (Black \& Dabareiner 2011). Thus, there is a considerable difference between the movements performed on a treadmill, in which animals travel in a straight line without explosive movements, and those performed during team roping.

With respect to temperature in the croup region, previous studies have shown that muscle regions, under normal conditions, have the capacity to return to baseline temperature after exercise much faster than surfaces without muscles because of their larger surface area. However, contrary to the findings by Costa et al. (2009), the temperature in the croup region (right side) in the RTG did not return to baseline level after 24 hours. During team roping, muscle contraction on the right side of the croup is more intense than that on the left side because it assists with the turning movement of the animal to the left. The high temperature in these regions is probably linked to the greater burden to which they are submitted. According to Turner (2011), myopathies of the croup are caused by tension in the long muscle, origin of the gluteus medius (in the sacroiliac region), gluteus medius body, and gluteus insertion in the major trochanter and third trochanter of the femur.

Overburden also affects the thoracic limbs of horses, since the temperatures in these regions only returned to baseline level between six and 24 hours after exercise. At the time the header ropes the steer, his horse makes a left turn and its right thoracic limbs support much of its weight, added to the strength to drag the steer. In turn, the heeler horse supports its weight on the left thoracic limb during the turn movement (Dabareiner 2011).

In the present study, temperature measurements taken 24 hours after exercise could confirm whether these specific regions need more time to return to baseline level. If this does not occur, another explanation for the presence of high temperature in these regions 24 hours after exercise may be related to localized subclinical inflammation. Comparison between the mean temperature values in the three regions and their corresponding baseline levels showed differences greater than $1^{\circ} \mathrm{C}$, namely, $1.6^{\circ} \mathrm{C}$ for the $\mathrm{LPL}, 1.3^{\circ} \mathrm{C}$ for the $\mathrm{RPL}$, and $1.6^{\circ} \mathrm{C}$ for the croup (right side). Difference of $1^{\circ} \mathrm{C}$ or $1.25^{\circ} \mathrm{C}$ between two anatomically symmetric regions is indicative of subclinical inflammation (Head \& Dyson 2001, Soroko et al. 2013). According to Dabareiner et al. (2005), injuries in roping horses are associated with their function in this sport modality. Horses mounted by headers present higher percentage of distal injuries in the forelimbs, whereas in those ridden by heelers the number of injuries is larger in their hind limbs.

Thus, the maintenance of temperature in the tendon (pelvic limb) and croup regions above the baseline level may be mainly associated with the need for longer heat dissipation time in these regions, since they are the most requested during movement, and secondly with maintenance of temperature above baseline level after 24 hours, which is suggestive of localized subclinical 
inflammation, early diagnosed by infrared thermography. Early diagnosis of inflammatory lesions has been reported in previous studies, and the change in superficial temperatures indicative of inflammation was verified two weeks before the animals presented with clinical signs (Vaden et al. 1980, Turner 2011). It is known that excessive and repetitive exercise can cause different types and levels of subclinical lesions in the collagenous matrix that cannot be repaired by tenocytes for various reasons, including insufficient rest period between episodes and simple overburden of cell capacity caused by high frequency or non-uniformity (Kane \& Firth 2014). Therefore, the probable subclinical inflammation in these animals may be associated with repetitive effort of these structures, since these animals are trained constantly and, consequently, lack the time interval necessary for recovery.

Findings of the present study clearly show that frequent training might lead to damage to anatomical structures essential for athlete horses, such as tendons and muscle groups; therefore, infrared thermography could be used as an important tool to avoid more serious injuries. According to Turner (2011), lesions with significant clinical potential can be identified and, accordingly, the training protocol can be readjusted to prevent further injury.

\section{CONCLUSIONS}

Team roping simulation increased the surface temperature of the distolateral thoracic and pelvic limb, croup, and thoracolumbar regions in both study groups, except for the eye temperature in the RTG.

Training frequency influenced the surface temperature profile, especially in the distolateral pelvic limb, croup, and thoracolumbar regions, because of the greater burden these regions are subjected during this type of exercise.

Acknowledgements.- The authors are grateful to Sao Paulo Research Foundation (FAPESP) for the financial support provided to this study (process no.2014/09362-5).

Conflict of interest statement.- The authors have no competing interests.

\section{REFERENCES}

Associação Brasileira do Quarto de Milha 2018. Estatísticas Gerais. Available at <http://servicosonline.abqm.com.br/estatistica> Accessed on Mar. 14, 2018.

Black J.B. \& Dabareiner R.M. 2011. The western performance horse, p.11651186. In: Ross W.M. \& Dyson S.J. (Eds), Diagnosis and Management of Lameness in the Horse. 2nd ed. Saunders Elsevier, St Louis.

Caiado J.C.C., Pissinate G.L., Souza V.R.C., Fonseca L.A. \& Coelho C.S. 2011. Lactacidemia e concentrações séricas de aspartato aminotransferase e creatinoquinase em equinos da raça Quarto de Milha usados em provas de laço em dupla. Pesq. Vet. Bras. 31(5):452-458. <http://dx.doi.org/10.1590/ S0100-736X2011000500014>

Costa A.P.D., Sobrinho B.L., Bogossian P., Mendonca L.P.V., Andrade V.A.A. \& Viana A.P. 2009. Thermography in the evaluation of hindlimb muscles in horses after a cross-country test. Proceedings 11 th International Congress of World Equine Veterinary Association, Guarujá, SP, p.3.

Dabareiner R.M. 2011. The western performance horse, p.1066-1071. In: Baxter G.M. (Ed.), Adams and Stashak's lameness in horse. 6th ed. WileyBlackwell, Iowa.

Dabareiner R.M., Cohen N.D., Carter G.K., Nunn S. \& Moyer W. 2005. Lameness and poor performance in horses used for team roping: 118 cases (2000-2003).
J. Am. Vet. Med. Assoc. 226(10):1694-1699. <http://dx.doi.org/10.2460/ javma.2005.226.1694><PMid:15906571>

Dunbar M.R., Johnson S.R., Rhyan J.C. \& Mccollum M. 2009. Use of infrared thermography to detect thermographic changes in mule deer (Odocoileus hemionus) experimentally infected with foot-and-mouth disease. J. Zoo Wildl. Med. 40(2):296-301. <http://dx.doi.org/10.1638/2008-0087.1> <PMid:19569476>

Eddy A.L., VanHoogmoed L. \& Snyder J. 2001. The role of thermography in management of equine lameness. Vet. J. 162(3):172-181. <http://dx.doi. org/10.1053/tvjl.2001.0618><PMid:11681868>

Gomide L.M.W., Panelli E.M., Campos G.S., Gravena K., Mendes L.C.N., Peiro J.R. \& Neto J.C.L. 2014. Thermography of team roping horses - preliminary results. J. Vet. Int. Med. 28:1121.

Head M.J. \& Dyson S. 2001. Talking the temperature of equine thermography. Comment Vet. J. 162(3):172-181. <PMid:11681865>

Hodgson D.R. 2014. Thermoregulation, p.108-124. In: Hodgson D., McKeever K. \& McGowan C. (Eds), The Athletic Horse: Principles and Practice of Equine Sports Medicine. 2nd ed. W.B. Saunders, Missouri. <http://dx.doi. org/10.1016/B978-0-7216-0075-8.00017-4>

Hodgson D.R. \& Rose R.J. 1994. Thermorregulation, p.182-202. In: Hodgson D.R. \& Rose R.J. (Eds), The Athletic Horse: principles and practice of equine sports medicine. W.B. Saunders, Philadelphia.

Johnson S.R., Rao S., Hussey S.B., Morley P.S. \& Traub-Dargatz J.L. 2011. Thermographic eye temperature as an index to body temperature in ponies. J. Equine Vet. Sci. 31(2):63-66. <http://dx.doi.org/10.1016/j. jevs.2010.12.004>

Kane J.C.P. \& Firth E.C. 2014. Tendon, ligament, bone and cartilage: anatomy, physiology, and adaptations to exercise and training, p.202-242. In: Hodgson D., McKeever K. \& McGowan C. (Eds), The Athletic Horse: principles and practice of equine sports medicine. 2nd ed. W.B. Saunders, Missouri. <http://dx.doi.org/10.1016/B978-0-7216-0075-8.00022-8>

Lash J. 1996. Regulation of skeletal muscle blood flow during contractions. Proc. Soc. Exp. Biol. Med. 211(3):218-235. <http://dx.doi.org/10.3181/00379727211-43965><PMid:8633102>

Lima R.A.S. \& Cintra A.G. 2016. Revisão do estudo do complexo do agronegócio do cavalo. Ministério da Agricultura, Pecuária e Abastecimento, Brasília, p.31-32.

Lovell D.K., Reid T.A. \& Rose R.J. 1987. Effects of maximal exercise on equine muscle changes in metabolites, $\mathrm{pH}$ and temperature, p.312-320. In: Gillespie J.R. \& Robinson N.E. (Eds), Equine Exercise Physiology, the science of exercise in the athletic horse. Vol.2. ICEEP Publications, Davis.

McConaghy F.F. 1994. Thermorregulation, p.182-202. In: Hodgson D.R. \& Rose R.J. (Eds), The Athletic Horse: principles and practice of equine sports medicine. W.B. Saunders, Philadelphia.

McConaghy F.F., Hodgson D.R., Rose R.J. \& Hales J.R. 1996. Redistribution of cardiac output in response to heat exposure in the pony. Equine Vet. J. 22(Suppl.):42-46. <http://dx.doi.org/10.1111/j.2042-3306.1996.tb05030. $\mathrm{x}><$ PMid:8894549>

McCutcheon L.J. \& Geor R.J. 2008. Thermoregulation and exercise-associated heat stress, p.382-386. In: Hinchcliff K.W., Geor R.J. \& Kaneps A.J. (Eds), Equine Exercise Physiology: the science of exercise in the athletic horse. Elsevier, Philadelphia. <http://dx.doi.org/10.1016/B978-070202857$1.50018-4>$.

Robertshaw D. 2006. Regulação da temperatura e o ambiente térmico, p.897908. In: Reece W.O. (Ed.), Dukes Fisiologia dos Animais Domésticos. 12a ed. Guanabara Koogan, Rio de Janeiro.

SAS Institute Inc. 2014. The SAS System, 9.3. SAS Institute Inc., Cary.

Schaefer A.L., Cook N.J., Church J.S., Basarab J., Perry B., Miller C. \& Tong A.K. 2007. The use of infrared thermography as an early indicator of bovine 
respiratory disease complex in calves. Res. Vet. Sci. 83(3):376-384. <http:// dx.doi.org/10.1016/j.rvsc.2007.01.008> <PMid:17349665>

Simon E.L., Gaughan E.M., Epp T. \& Spire M. 2006. Influence of exercise on thermographically determined surface temperatures of thoracic and pelvic limbs in horses. J. Am. Vet. Med. Assoc. 229(12):1940-1944. <http://dx.doi. org/10.2460/javma.229.12.1940><PMid:17173534>

Soroko M., Henklewski R., Filipowski H. \& Jodkowska E. 2013. The Effectiveness of thermographic analysis in equine orthopedics. J. Equine Vet. Sci. 33(9):760-762. <http://dx.doi.org/10.1016/j. jevs.2012.11.009>

Tanda G. 2016. Skin temperature measurements by infrared thermography during running exercise. Exp. Therm. Fluid Sci. 71:103-113. <http://dx.doi. org/10.1016/j.expthermflusci.2015.10.006>
Tunley B. \& Henson F. 2004. Reliability and repeatability of thermographic examination and the normal thermographic image of the thoracolumbar region in the horse. Equine Vet. J. 36(4):306-312. <http://dx.doi. org/10.2746/0425164044890652><PMid:15163036>

Turner T.A. 2011. Thermography, p.466-473. In: Baxter G.M. (Ed.), Adams and Stashak's Lameness in Horse. 6th ed. Wiley-Blackwell, Iowa.

Turner T.A., Pansch J. \& Wilson J.H. 2001. Thermographic assessment of Racing thoroughbreds. AAEP Proceedings 47:344-346.

Vaden M.F., Purohit R.C., McCoy D. \& Vaughan J.T. 1980. Thermography: a technique for subclinical diagnosis of osteoarthritis. Am. J. Vet. Res. 41(8):1175-1179. <PMid:7447111>

Yanmaz L.E., Okumus Z. \& Dogan E. 2007. Instrumentation of thermography and its applications in horses. J. Anim. Vet. Adv. 6:858-862. 